\title{
Hydrogenophilus hirschii sp. nov., a novel thermophilic hydrogen-oxidizing $\beta$-proteobacterium isolated from Yellowstone National Park
}

\author{
Rüdiger Stöhr, ${ }^{\dagger} \dagger$ Arne Waberski, ${ }^{\ddagger} \ddagger$ Werner Liesack, ${ }^{2}$ Horst Völker, ${ }^{1}$ \\ Uta Wehmeyer ${ }^{1}$ and Michael Thomm ${ }^{1}$
}

1 Institut für Allgemeine Mikrobiologie, Am Botanischen Garten 1-9, 24118 Kiel, Germany

2 Max-Planck-Institut für Terrestrische Forschung, Karl-von-Frisch-Straße, 35043 Marburg, Germany
Author for correspondence: Michael Thomm. Tel: +49431880 4330. Fax: +494318802194. e-mail: mthomm@ifam.uni-kiel.de

A novel thermophilic hydrogen-oxidizing bacterium, Hydrogenophilus hirschii $\mathrm{Yel5a}^{\mathrm{T}}$ ( = DSM $11420^{\top}=\mathrm{JCM} 10831^{\top}$ ) has been isolated from the Angel Terrace Spring, Yellowstone National Park. The isolate was rod-shaped (1.0-1.5 $\times 0.8 \mu \mathrm{m})$ with a polarly inserted flagellum. Cells grew chemolithoautotrophically under an atmosphere of $\mathrm{H}_{2}$ and $\mathrm{CO}_{2}(80: 20)$ in the presence of low concentrations of $\mathrm{O}_{2}$ (optimum $2.5 \%$ ). Organotrophic growth occurred on complex organic substrates such as yeast extract and peptone and on organic acids. Carbohydrates and amino acids were not utilized. The strain grew between 50 and $67^{\circ} \mathrm{C}$; optimal growth occurred at a temperature of $63^{\circ} \mathrm{C}$. The pH optimum was 6.5. $\mathrm{NaCl}$ inhibited growth at concentrations higher than $1.5 \%$. The major respiratory lipoquinone was ubiquinone-8. Analysis of fatty acids of $\mathrm{Yel5a}^{\mathrm{T}}$ revealed a straight-chain saturated $C_{16: 0}$ as the major component followed by cyclo $C_{17: 0}$ and cyclo $C_{19: 0}$. The $G+C$ content of total DNA was $61 \mathrm{~mol} \%$. Phylogenetic analysis placed the strain in the $\beta$-proteobacteria. The $16 \mathrm{~S}$ rDNA sequence of strain $\mathrm{Yel}^{\mathrm{T}} \mathrm{a}^{\top}$ was related to that of Hydrogenophilus thermoluteolus. To our knowledge, Hydrogenophilus hirschii is the most thermophilic micro-organism found within the proteobacteria that grows in the temperature range $50-68{ }^{\circ} \mathrm{C}$.

Keywords: hydrogen oxidation, hot springs, thermophilic bacteria, proteobacteria, Hydrogenophilus

\section{INTRODUCTION}

Gram-negative bacteria with the ability to obtain energy from the oxidation of $\mathrm{H}_{2}$ have been known for a long time (Niklewski, 1910). The 'Knallgas' bacteria comprise an extremely diverse group of aerobic, chemolithotrophic bacteria (Bowien \& Schlegel, 1981). Most of these hydrogen bacteria are facultative chemolithoautotrophs. More than 20 genera have been

\footnotetext{
†Present address: Institut für Meereskunde, Düsternbrooker Weg 20, 24105 Kiel, Germany.

¥Present address: Biologische Bundesanstalt für Land- und Forstwirtschaft, Institut für Pflanzenvirologie, Mikrobiologie und biologische Sicherheit, 38104 Braunschweig, Germany.

Abbreviation: TTC, triphenyltetrazolium chloride.

The GenBank/EMBL/DDBJ accession numbers for the 16S rRNA gene sequences of $\mathrm{Yel}^{5} \mathrm{a}^{\top}$ and Mar3 are AJ131694 and AJ277439, respectively.
}

described, including 15 Gram-negative and 5 Grampositive genera. (Friedrich \& Schwarz, 1993). Most of the Gram-negatives are representatives of the $\alpha$ - and $\beta$ proteobacteria and are facultative autotrophs that grow better on organic substrates than under autotrophic conditions. They are able to obtain energy by oxidation of hydrogen via an electron transport chain and to reduce carbon dioxide, in most cases via the ribulose bisphosphate cycle (Aragno \& Schlegel, 1992). The best studied Gram-negative hydrogen oxidizers belong to the genera Alcaligenes, Ralstonia, Acidovorax, Paracoccus and Hydrogenophaga. (Aragno \& Schlegel, 1992; Yabuuchi et al., 1995) The latter genus contains several species that were formerly classified as Pseudomonas (Willems et al., 1989). Among Grampositive bacteria, Knallgas bacteria were identified within the genera Mycobacterium, Amycolata, Arthrobacter, Bacillus and Nocardia (Aragno \& Schlegel, 
1992; Friedrich \& Schwarz, 1993). The hyperthermophilic hydrogen-oxidizers Aquifex and Hydrogenobacter have been isolated from hot springs (Huber et al., 1992). The Aquifex lineage represents the earliest divergence yet encountered in the domain Bacteria (Burggraf et al., 1992). The unique phylogenetic position of hydrogen-oxidizing bacteria from geothermally heated environments has prompted an exploration of marine and continental hot springs for the existence of novel hydrogen bacteria thriving at high temperatures. Our search for thermophilic bacteria growing at temperatures between 60 and $70{ }^{\circ} \mathrm{C}$ revealed the presence of micro-organisms capable of obtaining energy by this type of metabolism in geothermally heated areas at a beach on the island of Ischia, Italy and in a hot spring of Yellowstone National Park, USA. Here, the isolate $\mathrm{Yel}^{5 \mathrm{a}^{\mathrm{T}}}$ from the Angel Terrace Spring, a fresh water pond in the Yellowstone National Park, is described as a novel species belonging to the genus Hydrogenophilus within the $\beta$-proteobacteria.

\section{METHODS}

Origin of samples. Strain $\mathrm{Yel} \mathrm{a}^{\mathrm{T}}$ was isolated from a water sample also containing sediment, taken from the Angel Terrace Spring $\left(69.3^{\circ} \mathrm{C}, \mathrm{pH} 6.5\right)$, Yellowstone National Park, USA. The sediment at this site was yellowish beige in colour and developed gas when treated with $\mathrm{HCl}$, suggesting that it contained carbonate. Both sediment and water from the spring were collected using a $100 \mathrm{ml}$ Sovirell bottle filled to the top and closed by a rubber stopper.

The sample from the island of Ischia (Italy) was collected by digging a $60 \mathrm{~cm}$ deep hole with a spade in a geothermally heated area at Maronti Beach. The $\mathrm{pH}$ of the seawater collected in this hole was 6.5 and the temperature was not elevated. Sample material was transferred to a $20 \mathrm{ml}$ tube. As it was originally planned to isolate anaerobes, the tube was closed tight with a rubber septum and reduced by the addition of sodium sulfide to a final concentration of $0 \cdot 2 \%$.

Culture media. For the isolation of $\mathrm{Yel}^{\mathrm{T}} \mathrm{a}^{\mathrm{T}}$ a medium described by Huber et al. (1992) modified by the omission of $\mathrm{NaCl}$ and the addition of $\mathrm{CaCl}_{2}$ was used. This medium (medium A) contained (in $\mathrm{g} \mathrm{l}^{-1}$ ): $\mathrm{MgSO}_{4} .7 \mathrm{H}_{2} \mathrm{O}, 7 \cdot 0$; $\mathrm{MgCl}_{2} .6 \mathrm{H}_{2} \mathrm{O}, 5 \cdot 5 ; \mathrm{KCl}, 0.65 ; \mathrm{NaBr}, 0 \cdot 1 ; \mathrm{NaHCO}_{3}, 2 \cdot 0$; $\mathrm{NH}_{4} \mathrm{Cl}, 0 \cdot 15 ; \mathrm{K}_{2} \mathrm{HPO}_{4}, 0 \cdot 1 ; \mathrm{CaCl}_{2} .2 \mathrm{H}_{2} \mathrm{O}, 0 \cdot 2 ; \mathrm{S}^{0}, 0 \cdot 5 ;$ trace minerals, $10 \mathrm{ml}$ (Huber et al., 1992). The $\mathrm{pH}$ was adjusted at room temperature to $7 \cdot 0$ with $\mathrm{H}_{2} \mathrm{SO}_{4}(25 \%)$. The medium was mixed with an UltraTurrax for $1 \mathrm{~min}$, deoxygenated under a stream of $\mathrm{N}_{2}$ for $20 \mathrm{~min}$ and dispersed in portions of $20 \mathrm{ml}$ in $120 \mathrm{ml}$ type III borosilicate glass bottles (Pharmapack) under an $\mathrm{N}_{2}$ atmosphere. Prior to sterilization for $90 \mathrm{~min}$ at $100^{\circ} \mathrm{C}$, the atmosphere was changed to $\mathrm{H}_{2} / \mathrm{CO}_{2}(80: 20 ; 300 \mathrm{kPa})$. After sterilization $100 \mu \mathrm{l}$ sterile $10 \% \mathrm{CaCO}_{3}$ solution was added. Air $(20 \mathrm{ml})$ was added to the headspace of the serum bottles by use of a sterile filter. Large cultures of $\mathrm{Yel}^{\mathrm{T}}$ were grown in a 1001 enamelcoated fermenter (Braun Biotech). The medium used for large-scale fermentation did not contain $\mathrm{S}^{0}$ or additional $\mathrm{CaCO}_{3}$. The fermenter was gassed with $1.21 \mathrm{~min}^{-1} \mathrm{H}_{2}$, $300 \mathrm{ml} \mathrm{min}^{-1} \mathrm{CO}_{2}$ and $120 \mathrm{ml} \mathrm{min}^{-1}$ air until a titre of $8 \times 10^{7}$ cells $\mathrm{ml}^{-1}$ was obtained. Then, the gassing with air was

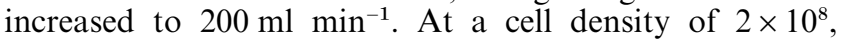
gassing with air was increased to $600 \mathrm{ml} \mathrm{min}^{-1}$. The explosion limit of air at $25^{\circ} \mathrm{C}$ and $150 \mathrm{kPa}$ is $25.5 \%$ (v/v) (Aragno \& Schlegel, 1992). Although this concentration was not reached in the gas mixture, the pipe containing the gas escaping from the fermenter was lead directly into an exhaust for the sake of safety.

For the cultivation of hydrogen-oxidizing bacteria originating from Maronti beach, medium B was used $\left(\mathrm{g} \mathrm{l}^{-1}\right)$ : Bacto-yeast extract, 0.5; Bacto-peptone, 5.0; NaCl, 19.4; $\mathrm{MgCl}_{2} .6 \mathrm{H}_{2} \mathrm{O}, \quad 12 \cdot 6$; $\mathrm{NaHCO}_{3}, \quad 0 \cdot 16 ; \mathrm{Na}_{2} \mathrm{SO}_{4}, 3 \cdot 24$; $\mathrm{CaCl}_{2} \cdot 2 \mathrm{H}_{2} \mathrm{O}, 2 \cdot 38 ; \mathrm{KCl}, 0 \cdot 56$; and $\mathrm{S}^{0}, 2 \cdot 0$. Trace element solution was added at a concentration of $1 \mathrm{ml}(1 \text { medium })^{-1}$. The trace element solution, prepared according to Balch et al. (1979) and modified according to Huber et al. (1992), contained $\left(\mathrm{g} \mathrm{l}^{-1}\right): \mathrm{KBr}, 40 ; \mathrm{SrCl}_{2} .6 \mathrm{H}_{2} \mathrm{O}, 28 \cdot 6 ; \mathrm{H}_{3} \mathrm{BO}_{3}, 11$; $\mathrm{Na}_{2} \mathrm{SiO}_{3} .5 \mathrm{H}_{2} \mathrm{O}, 2 ; \mathrm{NaF}_{2}, 1 \cdot 2 ; \mathrm{K}_{2} \mathrm{NO}_{4}, 0 \cdot 8 ; \mathrm{Na}_{2} \mathrm{HPO}_{4} .2 \mathrm{H}_{2} \mathrm{O}$, $0 \cdot 5$. The gas atmosphere was the same as for cultivation of samples originating from Angel Terrace. Serum bottles were incubated at 50,60 and $70{ }^{\circ} \mathrm{C}$ in a water bath with reciprocal shaking at 100 turns $\mathrm{min}^{-1}$.

To analyse carbon source utilization by Yel5a $\mathrm{a}^{\mathrm{T}}, 3 \mathrm{~g}$ PIPES buffer, adjusted to $\mathrm{pH} 7 \cdot 0$, was added to 11 medium as a buffer, whereas $\mathrm{NaHCO}_{3}$ was omitted from the medium. Various organic compounds (Table 1) were added at a concentration of $0 \cdot 2 \%$. The gas atmosphere was $99 \% \mathrm{H}_{2}$ $(300 \mathrm{kPa})$ and $1 \% \mathrm{O}_{2}$.

The gas atmosphere $\mathrm{N}_{2} / \mathrm{CO}_{2}(80: 20 ; 300 \mathrm{kPa})$ was used to test for the ability of $\mathrm{Yel}^{2} \mathrm{a}^{\mathrm{T}}$ to utilize sulfate, thiosulfate and sulfur as electron acceptors. To test for nitrogen fixation, media containing 3 g PIPES $1^{-1}$, pH 7.0, but no $\mathrm{NH}_{4} \mathrm{Cl}$ and $\mathrm{NaHCO}_{2}$, were inoculated under an atmosphere prepared as followed. Serum bottles were evacuated several times and pressurized with $\mathrm{H}_{2} / \mathrm{CO}_{2}(80: 20 ; 150 \mathrm{kPa})$. Air, $20-40 \mathrm{ml}$, was added with a syringe. The bottles were then pressurized at $300 \mathrm{kPa}$ with $\mathrm{N}_{2}$.

Isolation procedure. Pure cultures were obtained by repeated transfers of serial dilution cultures. The purity of the cultures was checked microscopically. Plating of cultures on medium A solidified with $1.5 \%(\mathrm{w} / \mathrm{w})$ agar (Gibco BRL) yielded yellow colonies consisting of uniform, highly motile short rods.

Measurement of growth. Growth of bacteria was determined by direct counting of cells cultivated in $120 \mathrm{ml}$ serum bottles in a Thoma Blau Brand chamber (Omnilab-Laborzentrum) with a depth of $0.02 \mathrm{~mm}$ under a phase-contrast microscope (Zeiss standard 16). Three parallel cultures were incubated at 100 r.p.m. in a reciprocally shaking water bath. The doubling times under various conditions were calculated from the slopes of growth curves. The $\mathrm{pH}$ was adjusted at room temperature $1 \mathrm{~d}$ before the cultures were inoculated and readjusted immediately prior to the inoculation. For $\mathrm{pH}$ measurement, an aliquot of the medium was removed with a syringe and the $\mathrm{pH}$ was determined by the use of universal $\mathrm{pH}$ paper (duotest; Macherey-Nagel).

Electron microscopy. A cell suspension of a well-grown culture was applied to Pioloform-covered 300 mesh $\mathrm{Cu}$ grid, washed once with glass-distilled water and shadow-casted after drying with $\mathrm{Pt} / \mathrm{C}$ at an angle of $35^{\circ}$. For thin sectioning, a culture was fixed overnight at $4{ }^{\circ} \mathrm{C}$ with $2 \%$ glutaraldehyde and $0.05 \%$ ruthenium red. After centrifugation $(10000 \mathrm{~g}, 10 \mathrm{~min})$, the cells were washed three times in cacodylate buffer $(0 \cdot 1 \mathrm{M}, \mathrm{pH} 7 \cdot 0)$. The pellet was mixed with Noble agar at $50^{\circ} \mathrm{C}$ and cut into pieces after hardening. Post-fixation of the agar cubes was performed for $3 \mathrm{~h}$ at $4{ }^{\circ} \mathrm{C}$ with a mixture of equal volumes of $\mathrm{OsO}_{4}(2 \%)$, ruthenium red $(0 \cdot 15 \%)$ and cacodylate buffer $(0 \cdot 2 \mathrm{M})$. The cubes were 
Table 1 Utilization of various carbon sources by $\mathrm{Yel} 5 \mathrm{a}^{\top}$ and some representatives of genera of Knallgas bacteria belonging to the $\beta$-proteobacteria

For Yel5 $\mathrm{a}^{\mathrm{T}}$, unless otherwise indicated, $0 \cdot 2 \%(\mathrm{w} / \mathrm{v})$ carbon source was added to the medium after sterilization. The data for Hydrogenophilus thermoluteolus were taken from Goto et al. (1978) and Hayashi et al. (1999). The data for Hydrogenophaga flava and Ralstonia eutropha were taken from Aragno \& Schlegel (1992). NA, Data not available. All four species studied were positive for utilization of acetate, pyruvate, DL-lactate, succinate, fumarate and DL-malate. All four species were negative for utilization of starch and D-xylose.

\begin{tabular}{|c|c|c|c|c|}
\hline Carbon source & $\begin{array}{c}\text { Hydrogenophaga } \\
\text { flava }\end{array}$ & $\begin{array}{c}\text { Hydrogenophilus } \\
\text { thermoluteolus } \mathrm{TH}-1^{\mathrm{T}}\end{array}$ & Yel5a $\mathbf{a}^{\mathrm{T}}$ & Ralstonia eutropha \\
\hline Meat peptone & NA & NA & + & NA \\
\hline Tryptone & NA & NA & + & NA \\
\hline Meat extract & NA & NA & + & NA \\
\hline Yeast extract & NA & NA & + & NA \\
\hline Lactose & NA & - & - & - \\
\hline D-Glucose & + & - & - & + \\
\hline D-Galactose & + & - & - & - \\
\hline D-Ribose & - & NA & - & - \\
\hline D-Fructose & + & NA & - & + \\
\hline Sucrose & + & - & - & - \\
\hline Citric acid & - & - & - & + \\
\hline$\alpha$-D-Maltose $/ \mathrm{H}_{2} \mathrm{O}$ & + & NA & - & - \\
\hline DL-Alanine & - & NA & - & + \\
\hline L-Proline & + & NA & - & + \\
\hline L-Histidine. $\mathrm{HCl}$ & + & NA & - & + \\
\hline Glycine & - & NA & - & - \\
\hline Glutamate & + & NA & + & + \\
\hline Methanol* & NA & NA & - & - \\
\hline Ethanol* & + & - & - & - \\
\hline Formate & NA & NA & - & + \\
\hline D-Gluconate & + & NA & + & + \\
\hline Benzoate & NA & - & - & + \\
\hline Benzylamine. $\mathrm{HCl}$ & NA & NA & - & - \\
\hline$m$-Hydroxybenzoic acid & + & - & - & + \\
\hline L-Mandelic acid & - & NA & - & + \\
\hline
\end{tabular}

* For Yel $5 \mathrm{a}^{\mathrm{T}}, 0 \cdot 2 \%(\mathrm{v} / \mathrm{v})$ of these substrates was used.

dehydrated in a graded series of ethanol using propylene oxide as intermediate medium and embedded in Spurr resin. Ultrathin sections were cut with a Reichert-Ultracut S Ultramicrotome. Sections were stained with uranyl acetate and lead citrate (Reynolds, 1963). Electron micrographs were taken using a Philips EM 300 electron microscope at $80 \mathrm{kV}$ on Kodak Electron Microscope Film (no. 4489).

Hydrogenase determination. Triphenyltetrazolium chloride (TTC) was used for a qualitative examination of hydrogenase activity (Aragno \& Schlegel, 1992). A freshly prepared TTC solution $(0 \cdot 1 \%, \mathrm{w} / \mathrm{v})$ was sterilized by filtration and dropped directly onto colonies. After incubation for $10 \mathrm{~min}$ in the dark under a hydrogen-free atmosphere, only colonies which used endogenous substrate and impurities of the agar were stained red. Additional incubation under a hydrogen atmosphere stained colonies exhibiting hydrogenase activity. This method was not lethal for the organisms as growth of transferred stained cells occurred in liquid media.

Analyses of respiratory lipoquinones. Respiratory lipoquinones were separated into different classes (menaquinones and ubiquinones) by TLC on silica gel (Macherey-
Nagel), using hexane:tert-butylmethylether $(9: 1, \mathrm{v} / \mathrm{v})$ as a solvent. UV-absorbing bands corresponding to menaquinones or ubiquinones were removed from the plate and further analysed by HPLC. This step was carried out on a LDC Analytical (Thermo Separation Products) HPLC fitted with a reverse phase column $\left(2 \mathrm{~mm} \times 125 \mathrm{~mm}, 3 \mu \mathrm{m}, \mathrm{RP}_{18}\right.$; Macherey-Nagel) using methanol as eluent. Respiratory lipoquinones were detected at $269 \mathrm{~nm}$.

Analyses of fatty acids. Fatty acids were analysed as the methyl ester derivatives prepared from $10 \mathrm{mg}$ dry cell material. Fatty acid methyl esters were analysed by GC using a $0 \cdot 2 \mu \mathrm{m} \times 25 \mathrm{~m}$ non-polar capillary column and FID. The run conditions were as follows: injection and detector port temperature, $300{ }^{\circ} \mathrm{C}$; inlet pressure, $60 \mathrm{kPa}$; split ratio, $50: 1$; injection volume, $1 \mu \mathrm{l}$; with a temperature program of $130-310^{\circ} \mathrm{C}$ at a rate of $4{ }^{\circ} \mathrm{C} \mathrm{min}^{-1}$.

DNA base composition. The DNA $\mathrm{G}+\mathrm{C}$ content was determined by HPLC according to Mesbah et al. (1989). Non-methylated lambda DNA (Sigma) was used as a standard.

DNA isolation. About $5 \mathrm{mg}$ lyophilized cells (a tip of a spatula) was resuspended in $150 \mu$ sterile distilled water. A 
preincubation of $10 \mathrm{~min}$ at $37^{\circ} \mathrm{C}$ was followed by the addition of $567 \mu \mathrm{l}$ Tris/EDTA buffer $(10 \mathrm{mM}, \mathrm{pH} 8 \cdot 0), 30 \mu \mathrm{l}$ $10 \%$ SDS solution and $3 \mu \mathrm{l}$ proteinase $\mathrm{K}\left(20 \mathrm{mg} \mathrm{ml}^{-1}\right.$; Sigma). After incubation for $1 \mathrm{~h}$ at $37^{\circ} \mathrm{C}, 100 \mu \mathrm{M} \mathrm{NaCl}$ and $80 \mu \mathrm{l} \quad 10 \%$ cethyltrimethylammoniumbromide were added and the mixture was incubated at $65^{\circ} \mathrm{C}$ for $30 \mathrm{~min}$. DNA was purified by treatment with phenol/chloroform $(1: 1)$ and twice with chloroform. It was precipitated with 2 propanol, washed with ethanol $(70 \%)$ and dissolved in $10 \mu \mathrm{l}$ sterile distilled water.

Phylogenetic analysis. The $16 \mathrm{~S}$ rRNA gene was amplified from isolated DNA using PCR. The reaction mixture for PCR contained: 5.0 $\mu \mathrm{l} \mathrm{RP}$-buffer [Tris $/ \mathrm{HCl} 1000 \mathrm{mM}, \mathrm{pH}$ 9.0, $\left.\left(\mathrm{NH}_{4}\right)_{2} \mathrm{SO}_{4}, 400 \mathrm{mM} ; \mathrm{MgCl}_{2}, 30 \mathrm{mM}\right] ; 10 \mu \mathrm{dNTP}$ mix (2.5 mM each); $2 \mu \mathrm{l} \mathrm{F-primer,} 12.5 \mu \mathrm{M}$ (5'-GAG TTT GAT CCT GGC TCA G, positions 9-27); $2 \mu$ l R-primer, $12.5 \mu \mathrm{M}$ (5'-TAC GGC TAC CTT GTT ACG ACT T, positions 1510-1492; Pharmacia) (Escherichia coli numbering); $0 \cdot 5 \mu \mathrm{l}$ DNA template (10-100 ng); $80 \mu$ l sterile distilled water; and was overlaid with $50 \mu 1$ mineral oil. Taq DNA polymerase (2.5 U; Roche Diagnostics) was added after a 'hot start'. PCR was performed in a Mastercycler (Eppendorf) using the following program: $4 \mathrm{~min}$ at $94{ }^{\circ} \mathrm{C}, 72^{\circ} \mathrm{C}$ during addition of the enzyme and 35 cycles of $45 \mathrm{~s}$ at $94{ }^{\circ} \mathrm{C}, 45 \mathrm{~s}$ at $50{ }^{\circ} \mathrm{C}$ and $75 \mathrm{~s}$ at $72{ }^{\circ} \mathrm{C}$. After 35 cycles, the mixture was held for $10 \mathrm{~min}$ at $72{ }^{\circ} \mathrm{C}$ and the cycler was cooled to $4{ }^{\circ} \mathrm{C}$.

The PCR product was purified using the Wizard PCR Prep DNA Purification system (Promega) and collected in $100 \mu \mathrm{l}$ double-distilled water. The concentration of DNA was estimated by electrophoresis on an agarose gel stained with ethidium bromide. Sequencing of the PCR product was done using the AmpliCycle Sequencing kit (Perkin Elmer). ${ }^{35} \mathrm{~S}$-ATP was used for labelling. The $16 \mathrm{~S}$ rRNA gene sequences of the new isolates were aligned using CLUSTAL W version 1.7 (Thompson et al., 1994) with sequences taken from the Ribosomal Database Project (RDP) (Olsen et al., 1991) and the EMBL Database. The following nucleotide positions were included in the phylogenetic analysis $(E$. coli numbering): 145-181, 219-450, 481-827, 850-997 and 1208-1365. Nucleotide positions that were missing in one or more sequences or regions of uncertain alignment were excluded from the phylogenetic analyses. Sequence programs of the PHYLIP (v. 3.5) package (Felsenstein, 1989) were used for calculations. A distance matrix was set up with DNADIST using the Jukes-Cantor equation (Jukes \& Cantor, 1969). The FITCH program generated a tree estimation with a random order input and a global rearrangement option activated. A bootstrap analysis with 1000 replicates was performed using the SEQBOOT program of the same package.

\section{RESULTS}

\section{Enrichment and isolation}

To investigate the possible existence of moderately thermophilic hydrogen-oxidizing bacteria in geothermally heated marine and freshwater environments, culture media suitable for the enrichment of chemolithoautotrophic Knallgas bacteria (medium A; see Methods) and for heterotrophic hydrogen oxidizers (medium B) were used. Medium A was inoculated with $1 \mathrm{ml}$ of the original sample collected from a freshwater hot spring in Yellowstone National Park (Angel Terrace; $T=69 \cdot 3{ }^{\circ} \mathrm{C}$ ) and medium B was inoculated with a $1 \mathrm{ml}$ sample taken at Maronti Beach, island of Ischia, Italy.

In the $60{ }^{\circ} \mathrm{C}$ enrichment culture from Angel Terrace, a rod-shaped bacterium was observed after $1 \mathrm{~d}$. No growth occurred in enrichment cultures incubated at 50 or $70{ }^{\circ} \mathrm{C}$. Enrichment cultures with material from Maronti Beach yielded rod-shaped bacteria after $1 \mathrm{~d}$ at $50{ }^{\circ} \mathrm{C}$, but not at 60 or $70^{\circ} \mathrm{C}$. These bacteria were transferred several times and the isolates $\mathrm{Yel}^{5 \mathrm{a}^{\mathrm{T}}}$ (Angel Terrace) and Mar3 (Maronti Beach) were obtained by repeated serial dilution. Partial sequence analyses of 16S rRNA genes revealed that strains $\mathrm{Yel}^{5 \mathrm{a}^{\mathrm{T}}}$ and Mar3 were closely related. Therefore, further investigations concentrated on strain $\mathrm{Yel}^{\mathrm{T}} \mathrm{a}^{\mathrm{T}}$, which was isolated at a higher temperature.

The medium used for cultivating strain Yel5 $\mathrm{a}^{\mathrm{T}}$ did not contain organic carbon. This made it probable that Yel5a ${ }^{\mathrm{T}}$ could utilize $\mathrm{CO}_{2}$ as sole carbon source. When hydrogen was replaced by $\mathrm{N}_{2}$ or when $\mathrm{O}_{2}$ was not added to the headspace of the cultures, growth did not occur. These observations indicated that this strain obtained its energy by oxidizing molecular hydrogen. In addition, its hydrogenase activity was detected in colonies using the TTC assay (see Methods).

\section{Morphological characteristics}

Cells of Yel5 $\mathrm{a}^{\mathrm{T}}$ were Gram-negative straight rods, $1.0-1.5 \mu \mathrm{m}$ long and $0.6-0.8 \mu \mathrm{m}$ wide. They were motile by means of one monopolar inserted flagellum (Fig. 1, top). Highly motile cells were observed microscopically at room temperature even in cultures stored for up to 3 months. Analysis of ultrathin sections revealed a cell wall structure typical for Gram-negative bacteria (Fig. 1, bottom). Cells of Mar3 were motile, Gram-negative straight rods with a length of $2 \mu \mathrm{m}$ and a width of $1 \mu \mathrm{m}$.

\section{Physiological characterization}

Yel5a $\mathrm{a}^{\mathrm{T}}$ grew well between 55 and $65^{\circ} \mathrm{C}$. Optimal growth, with a doubling time of $40 \mathrm{~min}$, was observed at $63^{\circ} \mathrm{C}$ (Fig. 2a). Growth of this strain occurred between pH 5.5 and 8.0 (Fig. 2b), with an optimum at $\mathrm{pH}$ 6.5. Salt was inhibitory. Only concentrations of $1.0-1.5 \% \mathrm{NaCl}$ were tolerated. At $\mathrm{NaCl}$ concentrations of $2 \%$ or higher, only poor growth was observed. Growth of hydrogen bacteria is often inhibited at high concentrations of $\mathrm{O}_{2}$, particularly at low cell densities. Analysis of the growth of $\mathrm{Yel}^{2} \mathrm{a}^{\mathrm{T}}$ in the presence of increasing concentrations of $\mathrm{O}_{2}$ in the headspace of the cultures showed that optimum growth occurred at an $\mathrm{O}_{2}$ concentration of $2.5 \%$. Growth was totally inhibited at $5 \% \mathrm{O}_{2}$. At an $\mathrm{O}_{2}$ concentration of $2.5 \%, 1.5 \times 10^{9}$ cells $\mathrm{ml}^{-1}$ were obtained within $10 \mathrm{~h}$ when the inoculum was $0.5 \%$. Mar3 was isolated from an enrichment culture at $50{ }^{\circ} \mathrm{C}$. Isolation and culturing were performed at $60{ }^{\circ} \mathrm{C}$ in medium $\mathrm{B}$ with a $\mathrm{NaCl}$ concentration of $3.5 \%$. 

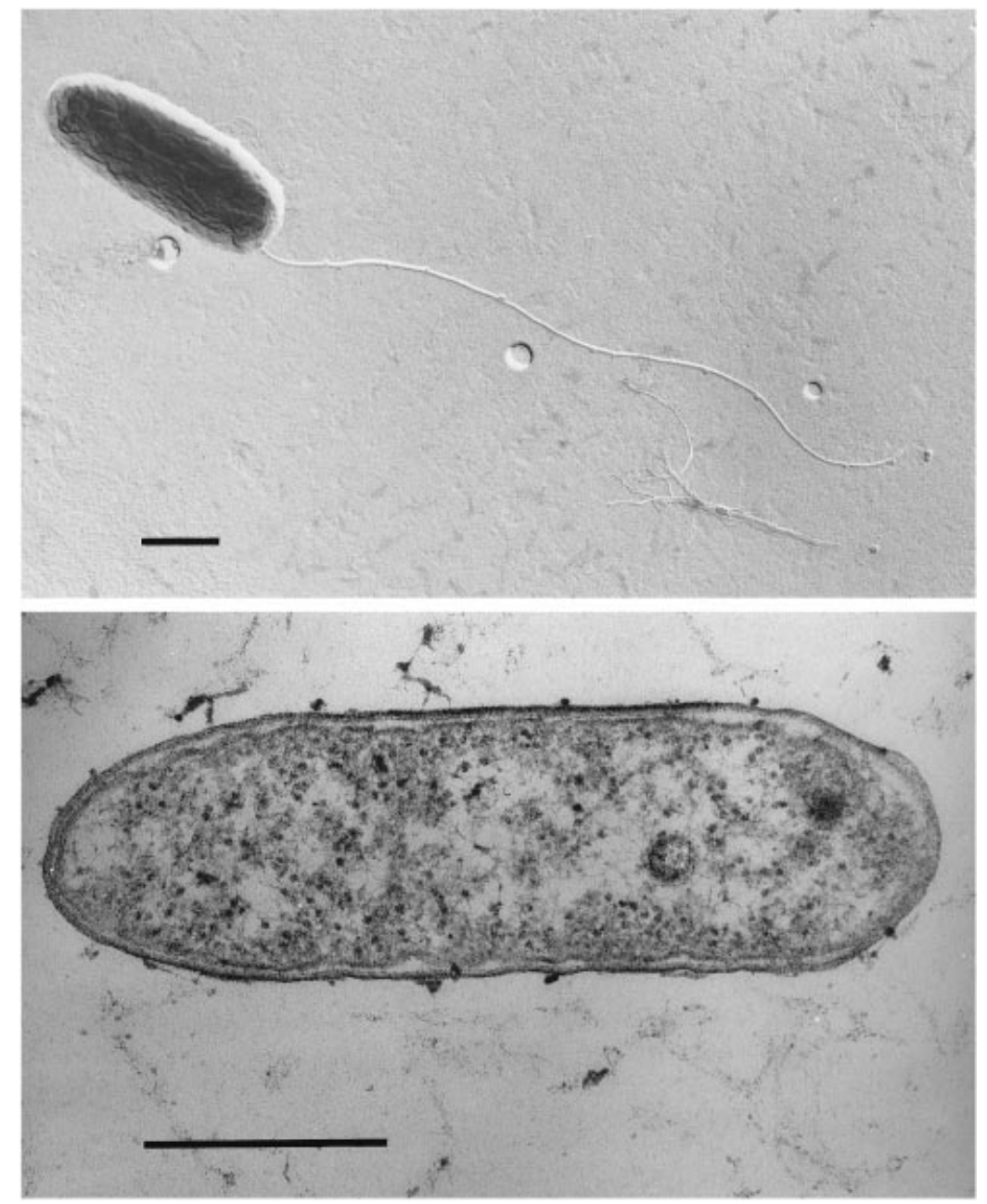

Fig. 1. Electrons micrograph of Hydrogenophilus hirschii: an ice-dried and platinumshaded cell with flagellum (top) and thin section of a cell (bottom). Bars, $0.5 \mu \mathrm{m}$.

\section{Carbon source utilization and other nutritional features}

Most hydrogen bacteria are facultative chemolithoautotrophs. To test whether Yel5a ${ }^{\mathrm{T}}$ could utilize organic carbon sources, this strain was cultivated under a hydrogen atmosphere with $1 \% \mathrm{O}_{2}$, but without $\mathrm{CO}_{2}$ in modified medium $\mathrm{A}$ supplemented with various carbon sources (Table 1). None of nine carbohydrates were utilized. Glutamate was the only amino acid tested that could be used. There was also no growth on methanol, ethanol or formate. However, good growth was observed on complex substrates like yeast extract, peptone, meat peptone and tryptone, as well as on organic acids such as fumarate, DL-malate, acetate, DL-lactate and pyruvate (Table 1). These observations indicated that $\mathrm{Yel}^{\mathrm{a}} \mathrm{a}^{\mathrm{T}}$ was facultatively autotrophic and that it could use some complex substrates and organic acids as a source for cellular carbon. It could also utilize gluconate. No growth on aromatic compounds was observed (Table 1).

To investigate whether Yel5a $\mathrm{a}^{\mathrm{T}}$ could grow in the absence of hydrogen and would be able to utilize organic substrates as energy sources, the organism was cultivated under an atmosphere of $99 \% \mathrm{~N}_{2}$ and $1 \% \mathrm{O}_{2}$ in a medium supplemented with $0 \cdot 2 \%(\mathrm{w} / \mathrm{v})$ yeast extract. Yel $5 \mathrm{a}^{\mathrm{T}}$ grew under these conditions, indicating that it was a facultative lithotroph with the ability to grow chemo-organotrophically. To understand the heterotrophic potential of the organism in more detail, its ability to grow on some carbon sources listed in Table 1 under an atmosphere containing only nitrogen and oxygen (99:1) was also studied. It was able to grow on glutamate, acetate, pyruvate, lactate, fumarate and malate. There was no growth with yeast extract under an atmosphere of pure nitrogen or $\mathrm{N}_{2} / \mathrm{CO}_{2}(80: 20, \mathrm{v} / \mathrm{v})$, indicating that the isolate was not capable of fermentative growth on this substrate.

To test the ability of Yel $5 \mathrm{a}^{\mathrm{T}}$ to use nitrate as a terminal electron acceptor, $\mathrm{O}_{2}$ was omitted from the gas phase and cells were cultivated anaerobically in the presence of $0 \cdot 1 \%(\mathrm{w} / \mathrm{v}) \mathrm{KNO}_{3}$. The strain grew under a $\mathrm{H}_{2} / \mathrm{CO}_{2}$ $(80: 20, \mathrm{v} / \mathrm{v})$ atmosphere with nitrate as electron acceptor, but not under an atmosphere containing only $\mathrm{N}_{2} / \mathrm{CO}_{2}(80: 20, \mathrm{v} / \mathrm{v})$ This observation provided evidence that Yel5a $\mathrm{a}^{\mathrm{T}}$ could grow chemoautotrophically by nitrate reduction. Medium A contained sulfate and $\mathrm{S}^{0}$. When $\mathrm{S}^{0}$ was omitted from this medium, Yel5a $\mathrm{a}^{\mathrm{T}}$ grew at the same rate and cell density as when $\mathrm{S}^{0}$ was present. Therefore, the strain was able to grow 

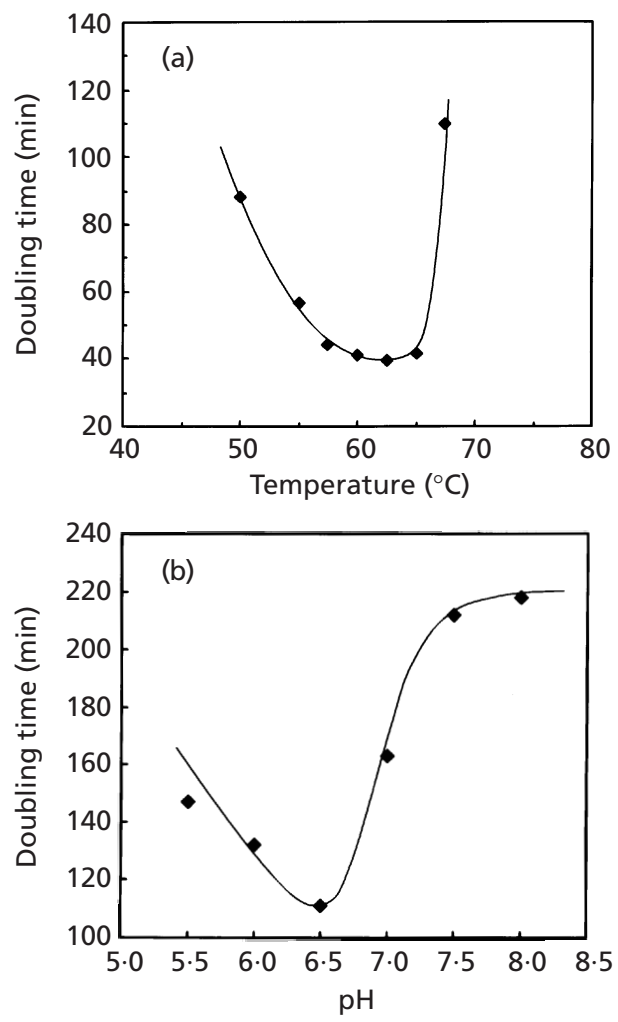

Fig. 2. Effects of (a) temperature and (b) $\mathrm{pH}$ on growth of Hydrogenophilus hirschii; cultures were incubated at $\mathrm{pH} 7$ and $60{ }^{\circ} \mathrm{C}$, respectively.

Table 2 Analysis of fatty acids of $\mathrm{Yel}^{\mathrm{T}} \mathrm{a}^{\top}$ and various Knallgas bacteria belonging to the $\beta$-proteobacteria

Data for Hydrogenophaga flava and Alcaligenes latus were taken from Willems et al. (1989). In Hydrogenophilus thermoluteolus, straight-chain saturated $\mathrm{C}_{16: 0}$ and $\mathrm{C}_{18: 0}$ are the major components of cellular fatty acids and 3-OH $\mathrm{C}_{10: 1}$ is the major 3-hydroxy cellular fatty acid (Hayashi et al., 1999). TR, Less than $0 \cdot 1 \% ;-$, not detected.

\begin{tabular}{|lccc|}
\hline Fatty acid & Yel5a $^{\text {T }}$ & $\begin{array}{c}\text { Hydrogenophaga } \\
\text { flava }\end{array}$ & $\begin{array}{c}\text { Alcaligenes } \\
\text { latus }\end{array}$ \\
\hline $3-\mathrm{OH} \mathrm{C} \mathrm{C}_{10: 0}$ & $2 \cdot 585$ & $2 \cdot 9$ & $7 \cdot 2$ \\
$\mathrm{C}_{12: 0}$ & $1 \cdot 658$ & $0 \cdot 2$ & $1 \cdot 1$ \\
$\mathrm{C}_{14: 0}$ & $2 \cdot 486$ & $2 \cdot 8$ & $2 \cdot 3$ \\
$\mathrm{C}_{16: 1}^{*}$ & $3 \cdot 120$ & $51 \cdot 7$ & $35 \cdot 3$ \\
$\mathrm{C}_{16: 0}$ & $55 \cdot 342$ & $19 \cdot 4$ & $19 \cdot 8$ \\
$\mathrm{Unknown}_{\text {Cyclo } \mathrm{C}_{17: 0}}$ & $0 \cdot 478$ & & \\
$\mathrm{C}_{18: 1} \omega 9 c^{\dagger}$ & $17 \cdot 92$ & $\mathrm{TR}$ & $\mathrm{TR}$ \\
$\mathrm{C}_{18: 1} \omega 7 c$ & $2 \cdot 265$ & $0 \cdot 4$ & $0 \cdot 9$ \\
$\mathrm{C}_{18: 0}$ & $1 \cdot 166$ & $13 \cdot 3$ & $15 \cdot 5$ \\
$\mathrm{Cyclo}_{19: 0}$ & $12 \cdot 98$ & $1 \cdot 5$ & $2 \cdot 7$ \\
\hline
\end{tabular}

* In the case of Yel5 $5 \mathrm{a}^{\mathrm{T}}$, the structure of this fatty acid component was $16: 1 \omega 7 c$.

$\dagger$ Oleic acid. with sulfate as sole source of cellular sulfur. Under an $\mathrm{N}_{2} / \mathrm{CO}_{2} / \mathrm{O}_{2}(80: 20: 1)$ atmosphere, no growth was observed when $\mathrm{S}^{0}$ or thiosulfate were added, indicating that these compounds could not be used as electron donors. In a medium lacking a nitrogen source, no growth was observed under an atmosphere containing approximately $40 \% \mathrm{H}_{2}, 10 \% \mathrm{CO}_{2}, 49 \% \mathrm{~N}_{2}$ and $1 \%$ $\mathrm{O}_{2}$ (or $2 \% \mathrm{O}_{2}$ ) indicating that this organism was unable to fix nitrogen.

\section{Analysis of fatty acids and respiratory quinones and DNA G + C content}

Fatty acids were analysed as methyl ester derivatives prepared from $10 \mathrm{mg}$ dry cell material. Analysis of the major fatty acids of $\mathrm{Yel}^{5 \mathrm{a}^{\mathrm{T}}}$ grown chemolithoautotrophically on hydrogen revealed straight-chain saturated $\mathrm{C}_{16: 0}$ as major component followed by cyclo $\mathrm{C}_{17: 0}$ and cyclo $\mathrm{C}_{19: 0}$ (Table 2 ). The major quinone was determined as ubiquinone-8.

The mean DNA G + C composition of Yel $5 \mathrm{a}^{\mathrm{T}}$ was $61 \cdot 0$ mol \% determined by HPLC (Mesbah et al., 1989).

\section{Phylogeny}

Twelve primers were used to determine a nearly complete sequence of 1400 bases of the 16S rRNA gene of $\mathrm{Yel}^{2} \mathrm{a}^{\mathrm{T}}$ and Mar3. The strains belong to the $\beta$ proteobacteria (Fig. 3). A phylogenetic analysis, including reference sequences from the $\beta$-subclass and using Escherichia coli as the outgroup organism, revealed that these novel isolates were closely related to Hydrogenophilus thermoluteolus. The similarity of the sequences of Yel5 $\mathrm{a}^{\mathrm{T}}$ and Mar3 to Hydrogenophilus thermoluteolus were 98 and $95.9 \%$, respectively. The sequence similarity between $\mathrm{Yel}^{5 \mathrm{a}^{\mathrm{T}}}$ and Mar3 was $95 \cdot 5 \%$. This group of sequences formed a cluster that is related to the genera Azoarcus and Zoogloea (Fig. 3).

\section{DISCUSSION}

The novel isolate Yel5 $\mathrm{a}^{\mathrm{T}}$ represents a new thermophilic hydrogen oxidizer within the phylum proteobacteria. The upper temperature limit for growth of this strain was $68^{\circ} \mathrm{C}$. To our knowledge, $\mathrm{Yel}^{\mathrm{T}} \mathrm{a}^{\mathrm{T}}$ is the most thermophilic member of the proteobacteria. Like Ralstonia eutropha, formerly Alcaligenes eutrophus (Yabuuchi et al., 1995), the best studied Gram-negative hydrogen bacterium, Yel5a ${ }^{\mathrm{T}}$ belongs to the $\beta$-proteobacteria. Both organisms share some phenotypic features like facultative chemolithoautotrophy, the ability to use organic acids and gluconate as carbon source, and the inability to utilize carbohydrates. However, Yel5 $\mathrm{a}^{\mathrm{T}}$ was unable to grow on amino acids such as L-alanine and L-proline and on citrate. These components can be utilized by all members of the genus Alcaligenes/Ralstonia (Kersters \& De Ley, 1984). Both Yel5a ${ }^{\mathrm{T}}$ and Alcaligenes / Ralstonia are also motile, but Yel $5 \mathrm{a}^{\mathrm{T}}$ is monopolarly flagellated, whereas Alcaligenes/Ralstonia strains possess 1-8 peritrichous 


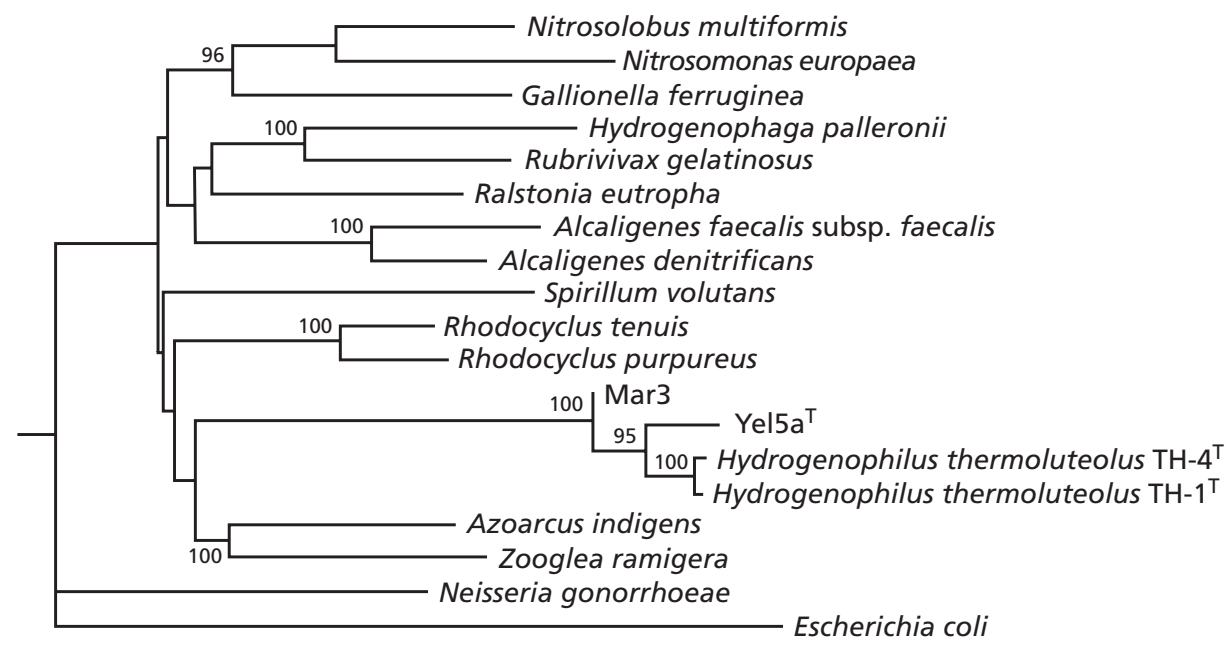

$0.05 K_{\text {nuc }}$

Fig. 3. Phylogenetic dendrogram based on $16 \mathrm{~S}$ rDNA sequences showing the relationship of the novel isolates $\mathrm{Yel}^{\mathrm{a}} \mathrm{a}^{\top}$ and Mar3 to selected members of the $\beta$-subdivision of proteobacteria. Confidence limits, expressed as percentages, were determined by bootstrap analysis with 1000 replicates. Only confidence limits of $95 \%$ and more are shown. Strains and accession numbers used for calculation are: Alcaligenes denitrificans ATCC 15173 ${ }^{\top}$, AF186070; Alcaligenes faecalis subsp. faecalis ATCC 8750 ${ }^{\top}$, M22508; Escherichia coli, J01695; Gallionella ferruginea, L07897; Hydrogenophaga palleronii DSM $63^{\top}$, AF019073; Hydrogenophilus thermoluteolus TH-1 ${ }^{\top}$ (=IFO 14978 ${ }^{\top}$ ), AB009829; Hydrogenophilus thermoluteolus TH-4 (=IFO 14593), AB009829; Neisseria gonorrhoeae strain FA 19, AJ239304; Nitrosomonas europaea, M96399; Nitrosolobus multiformis ATCC 25196 ${ }^{\top}$, L35509; Ralstonia eutropha ATCC 17697' ${ }^{\top}$, M32021; Rhodocyclus purpureus DSM 168 ${ }^{\top}$, M34132; Rhodocyclus tenuis ATCC 25093' ${ }^{\top}$, D16208; Rubrivivax gelatinosus ATCC 11169, M60682; Spirillum volutans ATCC 19554', M34131; and Zoogloea ramigera ATCC 19324, D14257.

flagella. In contrast to Alcaligenes/Ralstonia cells, which are not coloured, Yel5a ${ }^{\mathrm{T}}$ forms a yellow pigment. The optimal growth temperature of Alcaligenes species is between 20 and $37^{\circ} \mathrm{C}$, but Yel5a $\mathrm{a}^{\mathrm{T}}$ grew optimally between 55 and $65^{\circ} \mathrm{C}$. Yel5a ${ }^{\mathrm{T}}$ also differed from mesophilic hydrogen-oxidizing bacteria of the genus Hydrogenophaga, which are related to Alcaligenes, in terms of carbon source utilization (Willems et al., 1989) (Table 1). Yel5a ${ }^{\mathrm{T}}$ differed from the genera Ralstonia, Alcaligenes and Hydrogenophaga with respect to the major fatty acid composition (Table 2; Aragno \& Schlegel, 1992; Busse \& Auling, 1992; Urakami et al., 1995; Willems et al., 1989).

Like the thermophilic Hydrogenobacter and Aquifex, Yel $5 \mathrm{a}^{\mathrm{T}}$ was also isolated from a geothermal environment. However, these bacteria can be clearly distinguished. Firstly, Yel5a $\mathrm{a}^{\mathrm{T}}$ does not form a separate and deeply branching lineage but was found to be a member of the proteobacteria (Fig. 3). Secondly, in contrast to the obligate autotrophs Hydrogenobacter and Aquifex spp., Yel5a ${ }^{\mathrm{T}}$ uses a variety of organic compounds as sources for cellular carbon in the absence of $\mathrm{CO}_{2}$. Thirdly, the upper temperature limit for growth of $\mathrm{Yel}^{2} \mathrm{a}^{\mathrm{T}}\left(68^{\circ} \mathrm{C}\right)$ was significantly lower than that described for Aquifex $\left(90^{\circ} \mathrm{C}\right.$; Huber et al., 1992) or for Hydrogenobacter $\left(78^{\circ} \mathrm{C}\right.$; Kawasumi et al., 1984).
The closest relative to the new isolate $\mathrm{Yel} 5 \mathrm{a}^{\mathrm{T}}$ was found to be Hydrogenophilus thermoluteolus $\mathrm{TH}-1^{\mathrm{T}}$ with a phylogenetic distance of 0.0237 (Fig. 3). Yel5a ${ }^{\mathrm{T}}$ shares with this strain the ability to grow autotrophically and heterotrophically and on organic acids, as well as the inability to use carbohydrates (Table 1). Conversely, Yel $5 \mathrm{a}^{\mathrm{T}}$ differs clearly from Hydrogenophilus thermoluteolus in its temperature and oxygen optima. Yel5 $\mathrm{a}^{\mathrm{T}}$ grows between 50 and $68^{\circ} \mathrm{C}$ with an optimum at $63{ }^{\circ} \mathrm{C}$, Hydrogenophilus thermoluteolus grows optimally at $50-52{ }^{\circ} \mathrm{C}$ (Hayashi et al., 1999). Whereas Hydrogenophilus thermoluteolus showed best growth with oxygen concentrations of $22 \%$ (Goto et al., 1978), Yel5a ${ }^{\mathrm{T}}$ was identified as a microaerophilic organism with an $\mathrm{O}_{2}$ optimum of $2.5 \%$; no growth of Yel5a $\mathrm{a}^{\mathrm{T}}$ occurred at $5 \% \mathrm{O}_{2}$.

The major fatty acid composition of $\mathrm{Yel} 5 \mathrm{a}^{\mathrm{T}}$ revealed straight chain saturated $\mathrm{C}_{16: 0}$ as major component followed by cyclo $C_{17: 0}$ and cyclo $C_{19: 0}$ (Table 2 ). The cyclic fatty acids have not been described for Hydrogenophilus thermoluteolus in which $\mathrm{C}_{16: 0}$ and $\mathrm{C}_{18: 0}$ were found as the two major components (Hayashi et al., 1999).

Based on these findings, it is proposed that strain Yel5 $\mathrm{a}^{\mathrm{T}}$ is named as the new species Hydrogenophilus hirschii sp. nov. 


\section{Description of Hydrogenophilus hirschii sp. nov.}

Hydrogenophilus hirschii (hir'schi.i. N.L. gen. n. hirschii in honour of Peter Hirsch, in recognition of his fundamental contributions to the taxonomy of unusual bacteria).

Gram-negative rods, highly motile even at room temperature. Chemolithoautotrophic growth with hydrogen as electron donor and oxygen as electron acceptor. No growth with thiosulfate or sulfur as electron donor. Nitrate is utilized as electron acceptor under anaerobic conditions. Chemo-organotrophic growth on yeast extract, peptone, meat peptone, meat extract and on pyruvate, DL-malate, DL-lactate, acetate, fumarate, glutamate and gluconate. No growth on carbohydrates, aromatic compounds, L-alanine, Lproline or citric acid. No growth on methanol or ethanol. Ammonium can be utilized as a nitrogen source, sulfate as a sulfur source. Growth optimum between 60 and $65^{\circ} \mathrm{C}$. No growth at 70 or $45^{\circ} \mathrm{C}$. Inhibited by $\mathrm{NaCl}$ at concentrations greater than $2 \%$. Cells form a yellow pigment. The $\mathrm{G}+\mathrm{C}$ content of DNA was $61 \mathrm{~mol} \%$. Isolated from a water sample of Angel Terrace in Yellowstone National Park, USA. Growth factors are not required. Moderately thermophilic. The type strain is strain Yel5a $\mathrm{a}^{\mathrm{T}}\left(=\mathrm{DSM} 11420^{\mathrm{T}}\right.$ $=\mathrm{JCM} 10831^{\mathrm{T}}$ ). The strain belongs to the genus Hydrogenophilus within the $\beta$-proteobacteria.

\section{ACKNOWLEDGEMENTS}

This work was supported in part by the Fonds der Chemischen Industrie. Analyses of respiratory lipoquinones and fatty acids were carried out by Dr B. J. Tindall, DSMZ, Braunschweig, Germany. We would like to thank H. Preidel (Institut für Allgemeine Mikrobiologie, Universität Kiel) for large scale cultivation.

\section{REFERENCES}

Aragno, M. \& Schlegel, H. G. (1992). The mesophilic hydrogen oxidizing (Knallgas) bacteria. In The Prokaryotes, 2nd edn, pp. 3917-3933. Edited by A. Balows, H. G. Trüper, M. Dworkin, W. Harder \& K.-H. Schleifer. New York: Springer.

Balch, W. E., Fox, G. E., Magrum, L. J., Woese, C. R. \& Wolfe, R. S. (1979). Methanogens: re-evaluation of a unique biological group. Microbiol Rev 43, 260-296.

Bowien, B. \& Schlegel, H. G. (1981). Physiology and biochemistry of aerobic hydrogen-oxidizing bacteria. Annu Rev Microbiol 35, 405-452.

Burggraf, S., Olsen, G. J., Stetter, K. O. \& Woese, C. R. (1992). A phylogenetic analysis of Aquifex pyrophilus. Syst Appl Microbiol 15, 352-356.

Busse, H.-J. \& Auling, G. (1992). The genera Alcaligenes and 'Achromobacter'. In The Prokaryotes, 2nd edn, pp. 2544-2555. Edited by A. Balows, H. G. Trüper, M. Dworkin, W. Harder \& K.-H. Schleifer. New York: Springer.

Felsenstein, J. (1989). PHYLIP - phylogeny inference package (version 3.2). Cladistics 5, 164-166.
Friedrich, B. \& Schwarz, E. (1993). Molecular biology of hydrogen utilization in aerobic chemolithotrophs. Annu Rev Microbiol 47, 351-383.

Goto, E., Kodama, T. \& Minoda, Y. (1978). Growth and taxonomy of thermophilic hydrogen bacteria. Agric Biol Chem 42, 1305-1308.

Hayashi, N. R., Ishida, T., Yokota, A., Kodama, T. \& Igarashi, Y. (1999). Hydrogenophilus thermoluteolus gen. nov., sp. nov., a thermophilic, facultatively chemolitho-autotrophic, hydrogenoxidizing bacterium. Int J Syst Bacteriol 49, 783-786.

Huber, R., Wilharm, T., Huber, D. \& 7 other authors (1992). Aquifex pyrophilus gen. nov., sp. nov., represents a novel group of marine hyperthermophilic hydrogen-oxidizing bacteria. Syst Appl Microbiol 15, 340-351.

Jukes, T. H. \& Cantor, C. R. (1969). Evolution of protein molecules. In Mammalian Protein Metabolism, vol. 3, pp. 21-132. Edited by H. N. Munro. New York: Academic Press.

Kawasumi, T., Igarashi, Y., Kodama, T. \& Minoda, Y. (1984). Hydrogenobacter thermophilus gen. nov., sp. nov., an extremely thermophilic, aerobic, hydrogen-oxidizing bacterium. Int J Syst Bacteriol 34, 5-10.

Kersters, K. \& De Ley, J. (1984). Alcaligenes. In Bergey's Manual of Systematic Bacteriology, vol. 1, pp. 361-373. Edited by N. R. Krieg \& J. G. Holt. Baltimore: Williams \& Wilkins.

Mesbah, M., Premachandran, U. \& Whitman, W. B. (1989). Precise measurement of the $\mathrm{G}+\mathrm{C}$ content of deoxyribonucleic acid by high-performance liquid chromatography. Int $J$ Syst Bacteriol 39, 159-167.

Niklewski, B. (1910). Über die Wasserstoffoxidation durch Mikroorganismen. Jahresber Wiss Allg Mikrobiol 3, 251-264.

Olsen, G. J., Larsen, N. \& Woese, C. R. (1991). The ribosomal RNA Database project. Nucleic Acids Res 19, 2017-2018.

Reynolds, E. S. (1963). The use of lead citrate at high $\mathrm{pH}$ as an electron-opaque stain in electron microscopy. J Cell Biol 17, 208-212.

Thompson, J. D., Higgins, D. G. \& Gibson, T. J. (1994). CLUSTAL $\mathrm{W}$ : improving the sensitivity of progressive multiple sequence alignment through sequence weighting, position-specific gap penalties and weight matrix choice. Nucleic Acids Res 22, 4673-4680.

Urakami, T., Araki, H. \& Komagata, K. (1995). Characteristics of newly isolated Xanthobacter strains and fatty acid compositions and quinone system in yellow-pigmented hydrogen-oxidizing bacteria. Int J Syst Bacteriol 45, 863-867.

Willems, A., Busse, J., Goor, M. \& 8 other authors (1989). Hydrogenophaga, a new genus of hydrogen-oxidizing bacteria that includes Hydrogenophaga flava comb. nov. (formerly Pseudomonas flava), Hydrogenophaga palleronii (formerly Pseudomonas palleronii), Hydrogenophaga pseudoflava (formerly Pseudomonas pseudoflava and 'Pseudomonas carboxydoflava'), and Hydrogenophaga taeniospiralis (formerly Pseudomonas taeniospiralis). Int J Syst Bacteriol 39, 319-333.

Yabuuchi, E., Kosako, Y., Yano, I., Hotta, H. \& Nishiuchi, Y. (1995). Transfer of two Burkholderia and an Alcaligenes species to Ralstonia gen. nov.: proposal of Ralstonia pickettii (Ralston, Palleroni and Doudoroff 1973) comb. nov, and Ralstonia solanacearum (Smith 1896) comb. nov. and Ralstonia eutropha (Davis 1969) comb. nov. Microbiol Immunol 39, 897-904. 